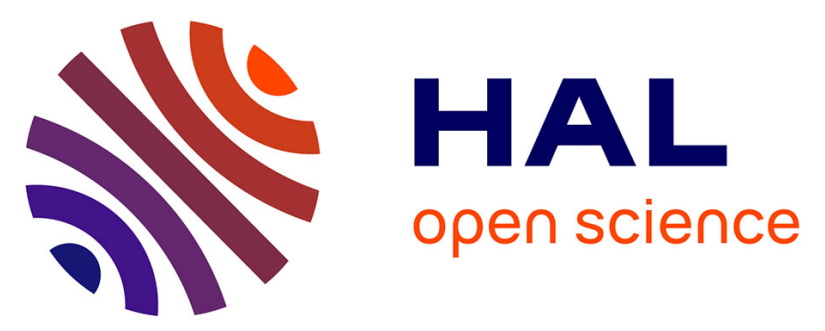

\title{
Significance of atmospheric inputs of calcium over the southwestern Mediterranean region: High mountain lakes as tools for detection
}

\author{
Elvira Pulido-Villena, I Reche, R Morales-Baquero
}

\section{To cite this version:}

Elvira Pulido-Villena, I Reche, R Morales-Baquero. Significance of atmospheric inputs of calcium over the southwestern Mediterranean region: High mountain lakes as tools for detection. Global Biogeochemical Cycles, 2006, 20, pp.GB2012. 10.1029/2005GB002662 . hal-00691383

\section{HAL Id: hal-00691383 \\ https://hal.science/hal-00691383}

Submitted on 29 Oct 2021

HAL is a multi-disciplinary open access archive for the deposit and dissemination of scientific research documents, whether they are published or not. The documents may come from teaching and research institutions in France or abroad, or from public or private research centers.
L'archive ouverte pluridisciplinaire HAL, est destinée au dépôt et à la diffusion de documents scientifiques de niveau recherche, publiés ou non, émanant des établissements d'enseignement et de recherche français ou étrangers, des laboratoires publics ou privés. 


\title{
Significance of atmospheric inputs of calcium over the southwestern Mediterranean region: High mountain lakes as tools for detection
}

\author{
Elvira Pulido-Villena, ${ }^{1,2}$ Isabel Reche, ${ }^{1,3}$ and Rafael Morales-Baquero ${ }^{1,3}$ \\ Received 18 November 2005; revised 16 February 2006; accepted 22 February 2006; published 2 June 2006.
}

[1] We quantified dry and wet atmospheric deposition of calcium over the southwest Mediterranean region and we assessed its impact on calcium dynamics of two high mountain lakes differing in morphometry and catchment characteristics. Atmospheric deposition of Ca averaged $40 \mathrm{mmol} \mathrm{m}^{-2} \mathrm{yr}^{-1}$, and it showed a seasonal pattern similar to that reported for Saharan dust export to the Mediterranean region, with maxima during spring and summer. $\mathrm{Ca}$ enrichment from nonmarine sources was significantly related to the TOMS (Total Ozone Mapping Spectrometer) aerosol index. Atmospheric inputs significantly affected $\mathrm{Ca}$ concentration of the selected lakes, which do not presumably receive significant $\mathrm{Ca}$ inputs from weathering. The intensity of the effect depended on their corresponding sensitivities to evaporation. Total atmospheric inputs of $\mathrm{Ca}$ to each study lake catchment (11300 and 3100 moles) were enough to explain the lake Ca content (5400 and 111 moles, respectively). The results obtained in this study reveal that atmospheric inputs, particularly Saharan dust deposition, may be a significant source of calcium to remote mountain lakes.

Citation: Pulido-Villena, E., I. Reche, and R. Morales-Baquero (2006), Significance of atmospheric inputs of calcium over the southwestern Mediterranean region: High mountain lakes as tools for detection, Global Biogeochem. Cycles, 20, GB2012, doi:10.1029/2005GB002662.

\section{Introduction}

[2] The Sahara Desert is the world's major source of soil dust to the atmosphere, with an annual production of $400-$ $700 \cdot 10^{6}$ tons per year, almost $50 \%$ of the global dust production [Schütz et al., 1981; D’Almeida, 1986; Swap et al., 1996]. Every year, massive airborne plumes of dust from the Sahara are exported to the North Atlantic Ocean by the predominant westerly winds. In the Mediterranean region, maximum loads occur during spring and summer, influenced by the presence of cyclones [Moulin et al., 1997].

[3] Saharan dust exhibits an appreciable content of calcium [Löye-Pilot et al., 1986], a key element in both terrestrial and aquatic biogeochemical cycles. In terrestrial ecosystems, calcium exists as a structural component of minerals, on the exchange complex, and as a cation in soil solution. In addition, $\mathrm{Ca}$ is relatively abundant in higher plants, in which it is a structural element [e.g., Likens et $a l ., 1998]$. On the other hand, $\mathrm{Ca}$ is tightly linked to global carbon cycle via the ocean carbonate-bicarbonate equilibrium [Schlesinger, 1997], and it is a crucial element for the acid-neutralizing capacity of freshwater ecosystems,

\footnotetext{
${ }^{1}$ Departamento de Ecología, Facultad de Ciencias, Universidad de Granada, Granada, Spain.

${ }^{2}$ Now at Laboratoire d'Océanographie de Villefranche-sur-Mer, CNRSUMR 7093, Villefranche-sur-Mer, France.

${ }^{3}$ Also at Instituto del Agua, Universidad de Granada, Granada, Spain.

Copyright 2006 by the American Geophysical Union. 0886-6236/06/2005GB002662
}

playing a major role on their sensitivity to acidification. Although atmospheric deposition has been recognized to be a major source of $\mathrm{Ca}$ to terrestrial ecosystems [Avila et al., 1998; Likens et al., 1998; Drouet et al., 2005], little is known about the significance of atmospheric dust as a source of $\mathrm{Ca}$ to aquatic ecosystems.

[4] During the 1970s and 1980s, the acidification of a high proportion of lakes in Europe and North America led to extensive studies on the impact of atmospheric deposition on lake chemistry [e.g. Sullivan et al., 1990; Kopáček et al., 1995; Tait and Thaler, 2000]. Recent research has revealed a slow but progressive recuperation of these ecosystems mainly due to a decrease of acid emissions [Kopáček et al., 1998; Stoddard et al., 1999]. However, it has recently been hypothesized that Saharan dust deposition may also contribute to this recovery [Rogora et al., 2004]. The high $\mathrm{CaCO}_{3}$ content of Saharan dust significantly increases the $\mathrm{pH}$ of rainwater [Löye-Pilot et al., 1986], and can counteract the effects of acidic deposition on ecosystems [Psenner and Nickus, 1986; Psenner, 1999].

[5] Most high mountain lakes are not exposed to direct anthropogenic impact and therefore can be used as sensors of environmental change [Wathne and Rosseland, 2000; Catalan et al., 2002]. Sierra Nevada is a high-mountain site located in the southwestern Mediterranean region. This area is an ideal site to detect the biogeochemical impact of dust deposition because (1) it is close to the Sahara desert $(70 \%$ of dust export is deposited within the first $2000 \mathrm{~km}$ [Jaenicke and Schütz, 1978]); (2) it has altitudes above $3000 \mathrm{~m}$ above sea level (asl) (the mainstream of Saharan dust transport is between 1500 and $4000 \mathrm{~m}$ asl [Talbot et al., 
Table 1. Morphometric, Chemical, and Biological Characteristics of the Study Lakes for the Ice-Free Periods of 2000, 2001, and 2002 ${ }^{\mathrm{a}}$

\begin{tabular}{|c|c|c|c|c|c|}
\hline & Units & \multicolumn{2}{|c|}{ La Caldera Lake } & \multicolumn{2}{|c|}{ Río Seco Lake } \\
\hline $\begin{array}{l}\text { Lake area } \\
\text { Catchment area } \\
\text { Maximum depth }^{\mathrm{b}}\end{array}$ & $\begin{array}{l}\text { ha } \\
\text { ha } \\
\text { m }\end{array}$ & & & & \\
\hline \multirow{2}{*}{ Maximum depth $^{\mathrm{b}}$} & & \multicolumn{2}{|c|}{ La Caldera Lake } & \multicolumn{2}{|c|}{ Río Seco Lake } \\
\hline & Units & Mean & Range & Mean & Range \\
\hline $\begin{array}{l}\mathrm{ANC}^{\mathrm{c}} \\
\mathrm{Ca} \\
\mathrm{NO}_{3}^{-\mathrm{c}} \\
\mathrm{SRP}^{\mathrm{c}} \\
\mathrm{TN}^{\mathrm{d}} \\
\mathrm{TP}^{\mathrm{d}} \\
\mathrm{DOC}^{\mathrm{c}} \\
\mathrm{Chl}^{\mathrm{a}}{ }^{\mathrm{d}, \mathrm{e}}\end{array}$ & $\begin{array}{r}\text { meq L } L^{-1} \\
\mu \mathrm{mol} \mathrm{L} L^{-1} \\
\mu \mathrm{mol} \mathrm{L} L^{-1} \\
\mu \mathrm{mol} \mathrm{L} \mathrm{L}^{-1} \\
\mu \mathrm{mol} \mathrm{L}{ }^{-1} \\
\mu \mathrm{mol} \mathrm{L} \mathrm{L}^{-1} \\
\mu \mathrm{mol} \mathrm{L}{ }^{-1} \\
\mu \mathrm{g} \mathrm{L}^{-1}\end{array}$ & $\begin{array}{r}0.31 \\
110 \\
10.1 \\
0.02 \\
23.6 \\
0.15 \\
60.5 \\
0.75\end{array}$ & $\begin{array}{r}0.23-0.43 \\
91-118 \\
0.9-20.6 \\
0-0.13 \\
7.2-41.0 \\
0.04-0.35 \\
23.3-145.7 \\
0.23-1.57\end{array}$ & $\begin{array}{r}0.12 \\
37 \\
1.4 \\
0.07 \\
27.6 \\
0.53 \\
145.0 \\
1.44\end{array}$ & $\begin{array}{r}0.05-0.20 \\
25-51 \\
0.1-4.1 \\
0-0.31 \\
3.4-52.3 \\
0.17-2.78 \\
62.1-283.5 \\
0.62-3.00\end{array}$ \\
\hline
\end{tabular}

${ }^{\mathrm{a} C h e m i c a l}$ characteristics: ANC, acid neutralizing capacity; $\mathrm{Ca}$, calcium concentration; $\mathrm{NO}_{3}{ }^{-}$, nitrate concentration; SRP, soluble reactive phosphorus; TN, total nitrogen; TP, total phosphorus; and DOC, dissolved organic carbon. Biological characteristics: Chl-a, chlorophyll-a.

${ }^{\mathrm{b}}$ From Morales-Baquero et al. [1999].

${ }^{\mathrm{c}}$ Data from Pulido-Villena [2004].

${ }^{\mathrm{d}}$ Data from Morales-Baquero et al. [2006].

enly data from 2001 and 2002.

1986]); and (3) there are around 50 oligotrophic and dilute lakes between 2800 and $3100 \mathrm{~m}$ asl that are likely sensitive to dust deposition. In fact, recent research has revealed a noticeably sensitivity of Sierra Nevada high mountain lakes to Saharan dust deposition, which affects their chlorophyll-a content and their nutrient status [Morales-Baquero et al., 2006].

[6] The main goal of this study was to explore the significance of atmospheric deposition as a source of $\mathrm{Ca}$ to aquatic ecosystems in the Southwestern Mediterranean region. For this purpose, we quantified dry and wet atmospheric deposition of calcium over Sierra Nevada and we assessed its impact on two high mountain lakes.

\section{Material and Methods}

\subsection{Atmospheric Deposition Sampling}

[7] Separate samples of dry and wet deposition were collected using two MTX $^{\circledR}$ ARS 1010 automatic deposition samplers located in two sites of Sierra Nevada. One sampler was installed in a high-altitude site at $2900 \mathrm{~m}$ asl $\left(37^{\circ} 03^{\prime} \mathrm{N}\right.$, $3^{\circ} 23^{\prime} \mathrm{W}$ ), and was collected weekly during the ice-free periods of 2000, 2001 and 2002. Because of technical difficulties, only bulk deposition was collected during the ice-free period of 2000. The other sampler was installed at $1000 \mathrm{~m}$ asl $\left(36^{\circ} 34^{\prime} \mathrm{N}, 3^{\circ} 17^{\prime} \mathrm{W}\right)$ and was collected weekly from November 2000 to December 2002. On each sampling date, dry and wet deposition buckets from both collectors were replaced and taken to the laboratory. Dry deposition was collected by rinsing the bucket with $1000 \mathrm{~mL}$ of Milli$\mathrm{Q}^{\mathrm{B}}$ ultrapure water, and this solution was saved for the chemical analyses. The volume of rain in the wet deposition bucket was recorded, and a $1000-\mathrm{mL}$ aliquot was used for analysis. If rain volume was $<1000 \mathrm{~mL}$, it was brought up to that volume with Milli-Q ${ }^{\circledR}$ ultrapure water.

\subsection{Study Lakes and Sampling}

[8] Two high-mountain lakes from Sierra Nevada (La Caldera and Rio Seco) that exhibit contrasting character- istics (Table 1) were selected. Both lakes are located above $3000 \mathrm{~m}$ asl and are ice-covered for 8-9 months every year. They do not stratify and have very simple food webs. Sierra Nevada lithology is characterized by a dominance of micaschists [Puga, 1976], which implies that soils in lake catchments have low weatherable base cation reserves. La Caldera is a seepage lake in rocky watershed with no terrestrial vegetation. In contrast, Rio Seco is located in a catchment partially covered $(\sim 15 \%)$ by alpine meadows and has two temporal inlets that drain water from the catchment.

[9] The study lakes were sampled weekly during the icefree periods of 2000, 2001 and 2002 for dissolved calcium concentration and oxygen isotopic composition (surrogate of evaporation), coinciding with the sampling of the atmospheric dust collector located at $2900 \mathrm{~m}$ asl. Samples from La Caldera (maximum depth $\approx 10 \mathrm{~m}$ ) were collected by pumping water from depths of 9, 7, 5, 3 and $1 \mathrm{~m}$ and mixing them in equal parts to produce a single integrated sample. Since Río Seco (maximum depth $\approx 3 \mathrm{~m}$ ) is shallower than La Caldera, samples from this lake were collected using a column sampler $(10 \mathrm{~cm}$ in diameter and $1 \mathrm{~m}$ in length) from 0 to $1 \mathrm{~m}$ depth.

\subsection{Chemical Analyses}

[10] Dissolved calcium concentration was analyzed by atomic absorption (detection limit $=2.5 \mu \mathrm{mol} \mathrm{L}{ }^{-1}$ ) in both lake samples and in dry and wet deposition samples after filtering them by Whatman $\mathrm{GF} / \mathrm{F}$ glass fiber filters. In addition, oxygen isotopic signature was determined in both lake samples using a Finnigan-MAT 251 mass spectrometer and isotopic values are reported using the $\delta$ notation in parts per mil (\%) relative to the international standard V-SMOW.

\subsection{Calculation of Deposition Rates and Calcium Enrichment Index}

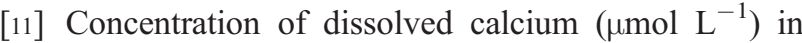
dry and wet deposition samples collected during each week was converted to units of daily deposition of dissolved 
calcium (hereafter, deposition of $\mathrm{Ca}$ ) using the following equation:

$$
\text { Deposition }\left(\mu \mathrm{mol} \mathrm{m}{ }^{-2} \mathrm{~d}^{-1}\right)=\frac{\text { Concentration }\left(\mu \mathrm{mol} \mathrm{L} \mathrm{L}^{-1}\right)}{A\left(\mathrm{~m}^{2}\right) \cdot 7(\text { days })} \cdot F
$$

where $A$ is the bucket area and $F$ is a correction factor for the rain volume. $F$ is equal to 1 for dry deposition samples and when the volume of rain is $<1 \mathrm{~L}$, but equal to volume of rain when $\geq 1 \mathrm{~L}$.

[12] The calcium enrichment $\left(\mathrm{E}_{\mathrm{Ca}}\right)$, considered as an index of nonmarine calcium sources, was obtained following Löye-Pilot et al. [1986],

$$
E_{C a}=\frac{(\mathrm{Ca} / \mathrm{Na})_{\text {atm }}}{(\mathrm{Ca} / \mathrm{Na})_{\text {seawater }}},
$$

where $(\mathrm{Ca} / \mathrm{Na})_{a t m}$ is the molar ratio between $\mathrm{Ca}$ and $\mathrm{Na}$ in total (dry + wet) atmospheric deposition, and $(\mathrm{Ca} / \mathrm{Na})_{\text {seawater }}$ is the molar ratio between these two cations in seawater $\left((\mathrm{Ca} / \mathrm{Na})_{\text {seawater }}=0.088 ;\right.$ Drever $\left.[1982]\right)$.

\subsection{Remote Sensing}

[13] To assess whether atmospheric deposition of $\mathrm{Ca}$ from nonmarine sources $\left(\mathrm{E}_{\mathrm{Ca}}\right)$ was related to aerosol content in the troposphere, we used the aerosol index developed by the Ozone Processing Team (NASA/GSFC) from measured radiances by the Total Ozone Mapping Spectrometer (TOMS) on board the NASA Earth Probe satellite. This index has been successfully applied to the study of Saharan dust [Chiapello et al., 1999] and has been found to agree with more specific detection tools such as the European Aerosol Research Lidar Network (EARLINET) [Ansmann et al., 2003]. We used weekly averages of daily TOMS data (NASA Goddard Space Flight Center [Torres et al., 1998, 2002]) given for $36.5^{\circ} \mathrm{N}, 4.375^{\circ} \mathrm{W}$. Moreover, to explore the origin of particularly high episodes of $\mathrm{Ca}$ deposition, we computed air back-trajectories using the Hybrid SingleParticle Lagrangian Integrated Trajectories (HYSPLIT) trajectory model [Draxler and Rolph, 2003; Rolph, 2003] provided by the NOAA Air Resources Laboratory (ARL). Five-day back-trajectories were obtained for both study altitudes (1000 and $3000 \mathrm{~m}$ asl).

\subsection{Statistical Analysis}

[14] The correlation between two variables is indicative of a common cause [Sokal and Rohlf, 1995], and it has been typically used to assess the synchrony of one variable between two neighboring lakes, indicative of extrinsic forcing [Magnuson et al., 1990; Baines et al., 2000]. In this study, we performed Pearson correlation analyses to explore the temporal coherence of calcium concentration between the study lakes. In addition, to assess the impact of $\mathrm{Ca}$ atmospheric deposition and lake oxygen isotopic signature (indicative of evaporation) on $\mathrm{Ca}$ dynamics in the study lakes we performed single and multiple regression analyses with total (dry + wet) $\mathrm{Ca}$ deposition and $\delta^{18} \mathrm{O}$ as independent variables and lake $\mathrm{Ca}$ concentration as the dependent variable. The significance of the difference between regres-

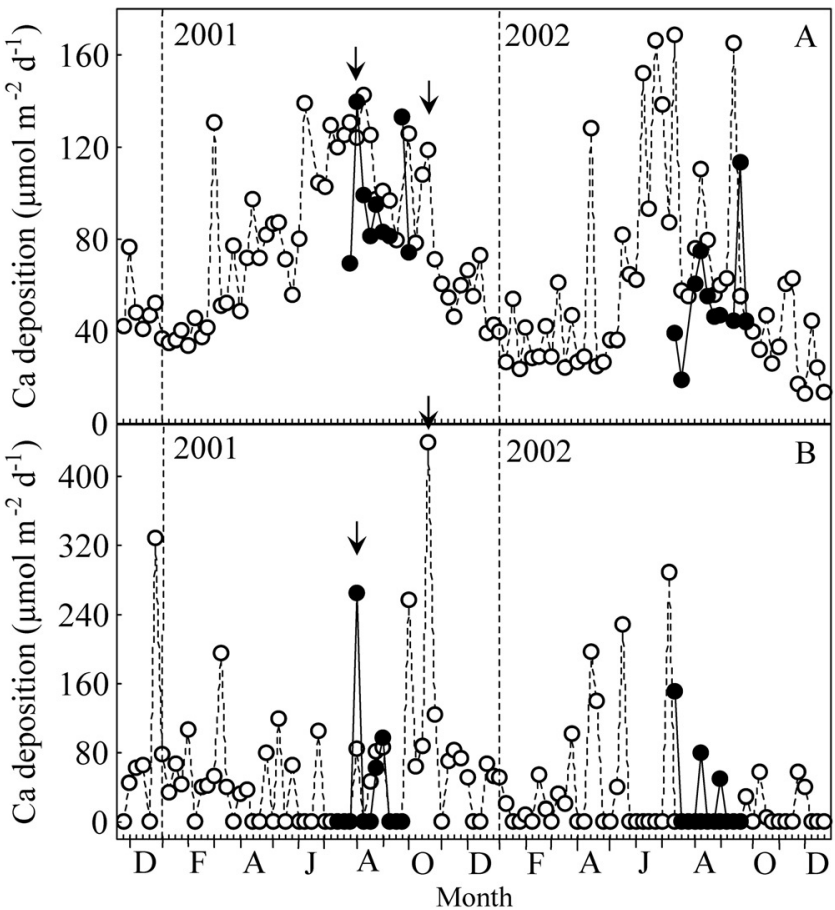

Figure 1. Seasonal dynamics of (a) dry and (b) wet atmospheric deposition of calcium $\left(\mathrm{Ca} ; \mu \mathrm{mol} \mathrm{m} \mathrm{m}^{-2} \mathrm{~d}^{-1}\right)$ at $1000 \mathrm{~m}$ asl (open symbols) and at $2900 \mathrm{~m}$ asl (solid symbols). Note the different scale for each figure. The arrows indicate the selected dates for air backward trajectories shown in Figure 2.

sion line slopes was tested using an F-test [Sokal and Rohlf, 1995].

\section{Results}

\subsection{Dry and Wet Deposition of Calcium (Ca)}

[15] Dry deposition of $\mathrm{Ca}$ at $1000 \mathrm{~m}$ asl ranged from $13 \mu \mathrm{mol} \mathrm{m} \mathrm{m}^{-2} \mathrm{~d}^{-1}$ to $168 \mu \mathrm{mol} \mathrm{m} \mathrm{m}^{-2} \mathrm{~d}^{-1}$, and it showed a clear seasonal pattern with maximum values during spring and summer (Figure 1a). At $2900 \mathrm{~m}$ asl, during the ice-free period of 2000, bulk deposition ranged from 34 to $123 \mu \mathrm{mol}$ $\mathrm{m}^{-2} \mathrm{~d}^{-1}$, and dry deposition ranged from 69 to $139 \mu \mathrm{mol}$ $\mathrm{m}^{-2} \mathrm{~d}^{-1}$ in 2001 , and from 19 to $113 \mu \mathrm{mol} \mathrm{m} \mathrm{m}^{-1}$ in 2002 (Figure 1a). Wet deposition of $\mathrm{Ca}$ ranged from 0 to $439 \mu \mathrm{mol} \mathrm{m} \mathrm{m}^{-2} \mathrm{~d}^{-1}$ at $1000 \mathrm{~m}$ asl, and from 0 to $266 \mu \mathrm{mol}$ $\mathrm{m}^{-2} \mathrm{~d}^{-1}$ in 2001 and from 0 to $152 \mu \mathrm{mol} \mathrm{m} \mathrm{m}^{-2} \mathrm{~d}^{-1}$ in 2002 at $2900 \mathrm{~m}$ asl. Wet deposition of $\mathrm{Ca}$ did not exhibit any seasonal trend (Figure 1b).

[16] Table 2 shows annual and ice-free period cumulative $\mathrm{Ca}$ deposition at $1000 \mathrm{~m}$ and $2900 \mathrm{~m}$ asl. Total Ca deposition was slightly higher in 2001 than in 2002. The relative contribution of dry deposition to total Ca inputs at $1000 \mathrm{~m}$ asl was $59 \%$ and $69 \%$ in 2001 and 2002, respectively.

[17] Dry and wet deposition of $\mathrm{Ca}$ at both altitudes showed an average $\mathrm{Ca}$ : $\mathrm{Na}$ molar ratio 2 orders of magnitude higher (1.7 and 1.5, respectively) than seawater. The calcium enrichment index $\left(\mathrm{E}_{\mathrm{Ca}}\right)$ in total $(\mathrm{dry}+\mathrm{wet})$ atmo- 
Table 2. Annual and Ice-Free Period Cumulative Deposition of Calcium $\left(\mathrm{mmol} \mathrm{m}^{-2}\right)$ at the Study Sites Located at $1000 \mathrm{~m}$ asl and $2900 \mathrm{~m}$ as

\begin{tabular}{|c|c|c|c|c|c|c|}
\hline \multirow[b]{2}{*}{ Period } & \multirow{2}{*}{$\begin{array}{c}\text { Meters Above } \\
\text { Sea Level }\end{array}$} & \multirow{2}{*}{$\begin{array}{l}2000 \\
\text { Bulk } \\
\end{array}$} & \multicolumn{2}{|c|}{2001} & \multicolumn{2}{|c|}{2002} \\
\hline & & & Dry & Wet & Dry & Wet \\
\hline nual & 1000 & & 28.2 & 20.0 & 20.8 & 9.4 \\
\hline ce-free period & 2900 & 5.7 & 6.0 & 3.0 & 3.8 & 2.0 \\
\hline & 1000 & & 7.2 & 3.9 & 6.9 & 0.2 \\
\hline
\end{tabular}

spheric deposition at both altitudes was significantly related to the TOMS index $(n=54 ; r=0.37 ; p<0.01)$. Air backtrajectories showed an African origin of the highest $\mathrm{Ca}$ inputs registered in this study. Figure 2 shows two examples of these air back-trajectories. The first example (Figure 2a) corresponds to a major atmospheric input of Ca registered in summer 2001 at both study altitudes (Figure 1). The second one (Figure 2b) corresponds to a strong Saharan dust outbreak that affected Europe between 11 and 16 October 2001 [Ansmann et al., 2003] and that resulted in the highest $\mathrm{Ca}$ deposition rate registered in the study period (Figure 1).

\subsection{Impact of Atmospheric Deposition on Lake Ca Dynamics}

[18] Ca concentration in La Caldera ranged from 91 to $118 \mu \mathrm{mol} \mathrm{L}^{-1}$ (mean value, $108 \pm 1 \mu \mathrm{mol} \mathrm{L}^{-1}$ ) and was always higher than in Río Seco that ranged from 25 to $51 \mu \mathrm{mol} \mathrm{L}^{-1}$ (mean value, $37 \pm 1 \mu \mathrm{mol} \mathrm{L}{ }^{-1}$ ) (Figure 3). During the three ice-free periods, Ca concentration showed a significant synchronous dynamic between both lakes $(n=$ $35 ; r=0.63 ; p<0.001)$. Oxygen isotopic signature of lake water $\left(\delta^{18} \mathrm{O}\right)$ was slightly higher in Rio Seco than in La Caldera during the three study periods and it showed a similar trend in both lakes with a progressive increase throughout the ice-free period (Figure 3).

[19] The Ca concentration of both lakes showed significant and positive relationships with the total (dry + wet) atmospheric deposition of $\mathrm{Ca}$ (Figure 4a). The slopes of the regression lines obtained did not show significant differences $\left(F_{(1,55)}=0.2 ; p=0.637\right)$. The $\delta^{18} \mathrm{O}$ was also related to $\mathrm{Ca}$ concentration in both lakes (Figure 4b), although the slope of the regression line obtained for Río Seco was significantly higher than for La Caldera $\left(F_{(1,64)}=\right.$ 12.6; $p<0.001)$.

[20] To determine the net effect of atmospheric deposition on lake $\mathrm{Ca}$ concentration against evapoconcentration (holding $\delta^{18} \mathrm{O}$ constant) we performed multiple regression analyses and calculated their partial correlation coefficients (Table 3). Subtle differences between the study lakes were found. In La Caldera, only $\mathrm{Ca}$ deposition had a significant effect on lake Ca concentration. In Río Seco, both variables significantly affected $\mathrm{Ca}$ dynamics, although the contribution of $\delta^{18} \mathrm{O}$ was more significant than that of atmospheric deposition (higher partial correlation coefficient).

\section{Discussion}

\subsection{Atmospheric Deposition of $\mathrm{Ca}$}

[21] Saharan dust contains a significant content of $\mathrm{CaCO}_{3}$ [Löye-Pilot et al., 1986] and, accordingly, Ca atmospheric deposition appears to show a global trend with decreasing values as distances from Sahara desert become longer. Indeed, total $\mathrm{Ca}$ atmospheric deposition registered in this study was similar to that reported for Northeastern Iberian Peninsula (24.8 $\mathrm{mmol} \mathrm{m}^{-2} \mathrm{yr}^{-1}$ [Avila et al., 1997, 1998]) and higher than that reported in the North of Europe (6.1 $\mathrm{mmol} \mathrm{m}^{-2} \mathrm{yr}^{-1}$ [Hultberg and Ferm, 2004]), the Pacific coast of California $\left(5.5 \mathrm{mmol} \mathrm{m}^{-2} \mathrm{yr}^{-1}\right.$ [Schlesinger

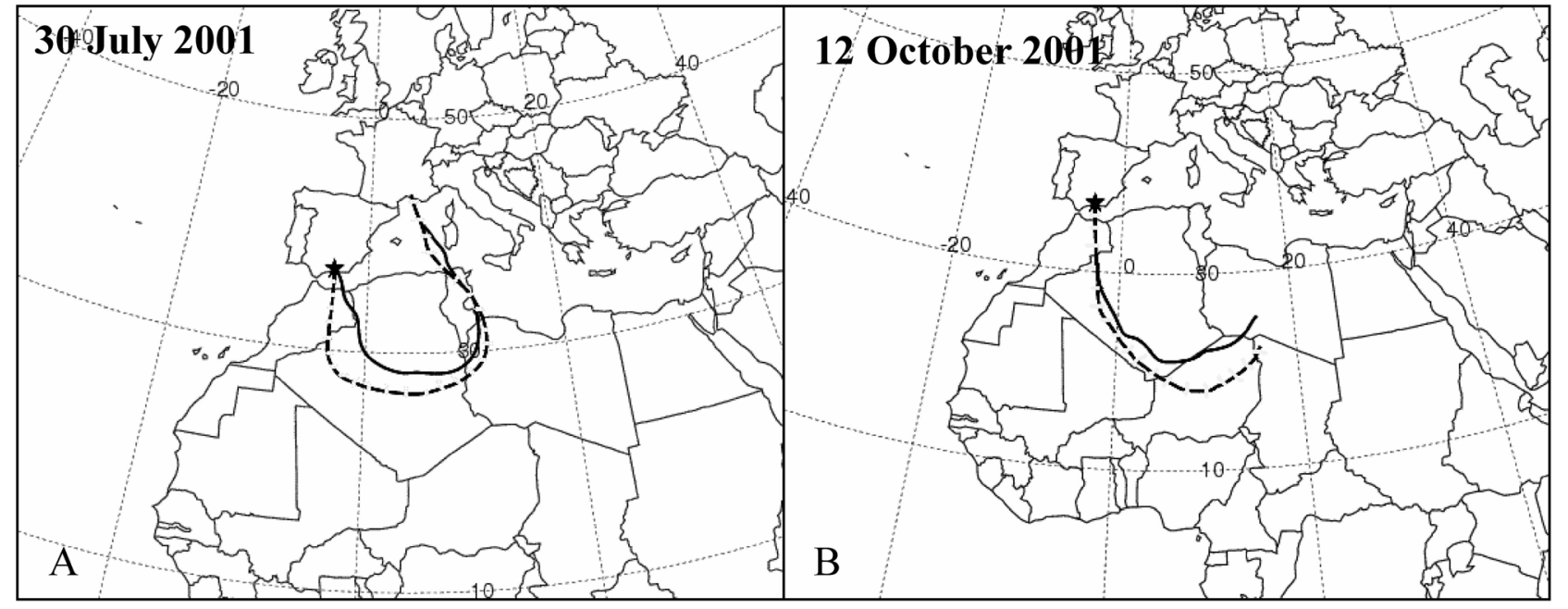

Figure 2. Five-day air back-trajectories arriving to the study site on (a) 30 July 2001 and (b) 12 October 2001 and corresponding to Ca deposition registered at both study altitudes on 31 July 2001 and at $1000 \mathrm{~m}$ asl on 15 October 2001. Dashed lines correspond to an arrival height of $3000 \mathrm{~m}$ asl and continuous lines to an arrival height of $1000 \mathrm{~m}$ asl. 


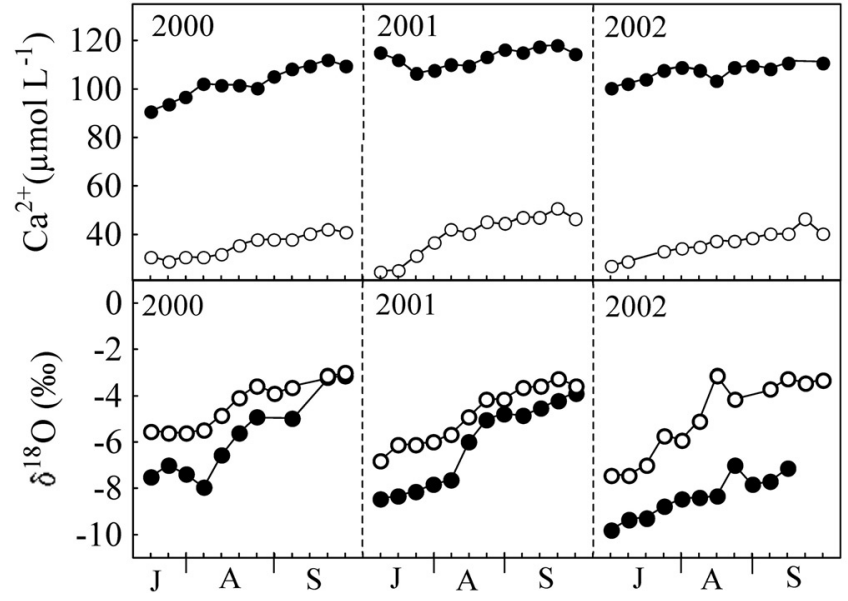

Figure 3. Dynamics of (top) calcium concentration $(\mathrm{Ca})$ and (bottom) oxygen isotopic signature $\left(\delta^{18} \mathrm{O}\right)$ in La Caldera Lake (solid symbols) and Río Seco Lake (open symbols) during the ice-free periods of 2000, 2001, and 2002.

et al., 1982]) or in the Hubbard Brook Experimental Forest (New Hampshire; $3.7 \mathrm{mmol} \mathrm{m}^{-2} \mathrm{yr}^{-1}$ [Likens et al., 1998]).

[22] The presence of mineral dust in the low atmosphere in Spain is known since long time and it was initially attributed to locally derived particle resuspension [Lange, 1960]. However, current research points out a high frequency of mineral dust plumes blown across from Africa to the Iberian Peninsula which significantly affect dust levels in the atmosphere [Rodriguez et al., 2001; Escudero et al., 2005; Moreno et al., 2005]. In this work, robust evidences indicated that $\mathrm{Ca}$ inputs to the study area were the result of long-range dust transport rather than an effect of local resuspension. First, $\mathrm{Ca}$ enrichment in atmospheric deposition was related to the TOMS aerosol index, which is well known to fail for the detection of dust at low layers of the atmosphere [Torres et al., 1998, 2002]; in addition, during simultaneous measurements of atmospheric deposition at both study altitudes (1000 $\mathrm{m}$ and $3000 \mathrm{~m}$ asl), similar Ca deposition values were registered. In both study altitudes, the high calcium enrichment in atmospheric deposition relative to typical sea salt content indicated a strong influence of lithosphere sources. The siliceous nature of the bedrock at high altitudes of Sierra Nevada Mountain rules out a local origin of these $\mathrm{Ca}$ inputs. In fact, the mean molar $\mathrm{Ca}: \mathrm{Na}$ ratio of atmospheric deposition measured in this study $(\approx 1.6)$ was noticeably higher than that reported for areas located far from Saharan dust influence (e.g., the Pacific coast of California, $\approx 0.037$ [Schlesinger et al., 1982]). Finally, the seasonal pattern of dry deposition of $\mathrm{Ca}$ observed in this study was similar to that reported for Saharan dust export to the Mediterranean region, with maxima in spring and summer [Moulin et al., 1997]. The above exposed rationale, along with the computed air backtrajectories, strongly underlines the significant contribution of Saharan dust to atmospheric inputs of $\mathrm{Ca}$ to the study area.

[23] These atmospheric $\mathrm{Ca}$ inputs might have important implications on global studies. For instance, recent esti- mates of inorganic carbon sedimentation in oceans are higher than the known inputs of calcium (e.g., weathering), suggesting that outputs have been overestimated or inputs underestimated, that one or more other inputs have not been identified, and/or that the oceans are not currently in steady state [Milliman, 1993; Schlesinger, 1997]. The results obtained in this study underline the need of considering the $\mathrm{Ca}$ atmospheric inputs to achieve a correct estimate of the oceanic $\mathrm{Ca}$ budget.

\subsection{Lakes as Tools for Detection of the Significance of Ca Inputs}

[24] Despite similar location and bedrock composition, the study lakes showed marked differences in their $\mathrm{Ca}$ concentrations. La Caldera exhibited a higher $\mathrm{Ca}$ concentration than other high mountain lakes located on similar bedrock [Tait and Thaler, 2000; Ventura et al., 2000; Kopáček et al., 2003]. Stream water in areas underlain by metamorphosed rocks often exhibit lower base cation con-
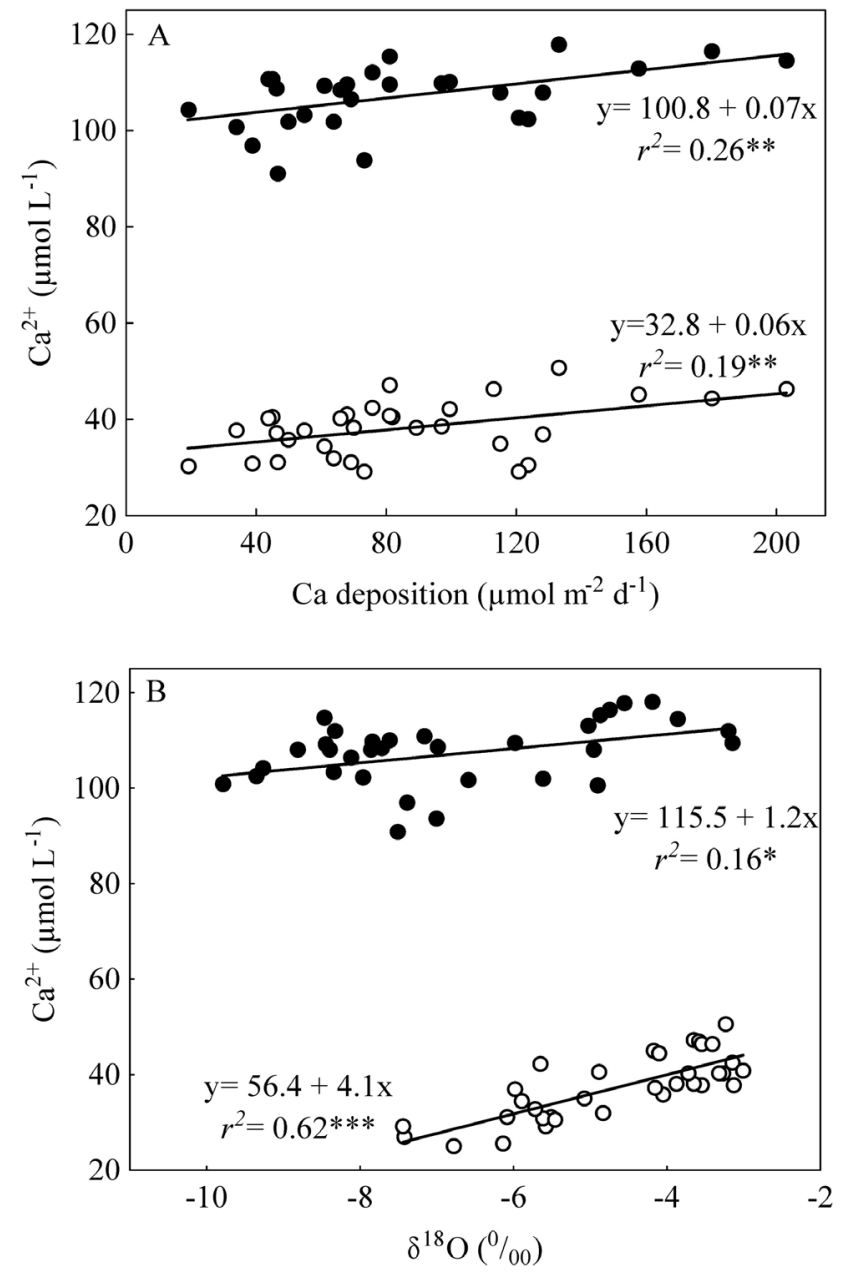

Figure 4. Relationship between total (dry + wet) atmospheric deposition of (a) calcium and (b) oxygen isotopic signature and calcium concentration in La Caldera Lake (solid symbols) and Río Seco lake (open symbols) during the ice-free periods of 2000, 2001, and 2002. 
Table 3. Results of the Multiple Regression Analyses Performed to Assess the Influence of Total (Dry + Wet) Ca Deposition and Oxygen Isotopic Signature (Surrogate of Evaporation) on $\mathrm{Ca}$ Concentration $\left(\mu \mathrm{mol} \mathrm{L} \mathrm{L}^{-1}\right)$ in La Caldera and Río Seco Lakes During the Ice-Free Periods of 2000,2001 , and $2002^{\mathrm{a}}$

\begin{tabular}{|c|c|c|c|c|c|c|}
\hline \multirow[b]{2}{*}{ Source of Variation } & \multicolumn{3}{|c|}{ La Caldera Lake } & \multicolumn{3}{|c|}{ Río Seco Lake } \\
\hline & $r$ & $b$ & $p$-level & $r$ & $b$ & $p$-level \\
\hline Ca deposition, $\mu \mathrm{mol} \mathrm{m}{ }^{-2} \mathrm{~d}^{-1}$ & 0.48 & 0.06 & 0.009 & 0.63 & 0.06 & \\
\hline $\begin{array}{l}\delta^{18} \mathrm{O}, \% 0 \\
\text { Intercept }\end{array}$ & 0.37 & $\begin{array}{r}1.18 \\
109.13\end{array}$ & $\begin{array}{l}0.055 \\
0.000\end{array}$ & 0.79 & $\begin{array}{r}3.71 \\
48.53\end{array}$ & $\begin{array}{l}0.000 \\
0.000\end{array}$ \\
\hline
\end{tabular}

${ }^{\mathrm{a}}$ Notation: $r$, partial correlation coefficient; $b$, nonstandardized regression coefficient. For La Caldera Lake, $n=28 ; r^{2}=0.39 ; p<0.001$. For Río Seco Lake, $n=30 ; r^{2}=0.72 ; p<0.001$

centrations than areas underlain by more reactive rocks (e.g., carbonates). These differences in chemical character are essentially due to weathering rate differences [Krám et al., 1997]. Considering that the study lake basins have low weatherable base cation reserves, the high $\mathrm{Ca}$ content of $\mathrm{La}$ Caldera suggested that it receives $\mathrm{Ca}$ from sources different than the weathering.

[25] The similarity of $\mathrm{Ca}$ dynamics between the study lakes indicated a regional response to large-scale disturbances such as atmospheric deposition and global change. Climate control on $\mathrm{Ca}$ concentration has been traditionally linked to evaporative processes caused by drought [Webster et al., 1996; Baines et al., 2000]. In fact, Ca concentration in both study lakes exhibited a progressive increase over the ice-free period (Figure 3), suggesting that evapoconcentration was an important mechanism affecting lake Ca dynamics. This was corroborated by the significant relationship obtained between $\mathrm{Ca}$ concentration and lake $\delta^{18} \mathrm{O}$ (Figure 4). However, not only evaporation but also atmospheric deposition of $\mathrm{Ca}$ influenced $\mathrm{Ca}$ dynamics in both study lakes, particularly in La Caldera (Figure 4 and Table 3). The role of dust deposition on $\mathrm{Ca}$ dynamics has only been reported for terrestrial ecosystems where it acts as a significant source of $\mathrm{Ca}$ to soils and terrestrial plants [Avila et al., 1998; Likens et al., 1998; Huntington, 2000]. By contrast, in aquatic ecosystems, rainfall has traditionally been considered as a factor that decreases, by dilution processes, solute concentration [Skjelkvåle and Wright, 1998]. This study establishes a direct link between dust deposition and lake Ca dynamics, evidencing that atmospheric deposition (dryfall and precipitation) can be a significant source of $\mathrm{Ca}$ to remote freshwater ecosystems.

[26] There were differences between lakes in the dependence of their $\mathrm{Ca}$ concentration on dust deposition. More- over, the slope of the relationship between $\delta^{18} \mathrm{O}$ and lake $\mathrm{Ca}$ concentration was significantly higher in Río Seco than in La Caldera, showing a greater influence of evaporation on $\mathrm{Ca}$ concentration in Río Seco. Three nonexclusive reasons can be proposed to explain these lake-specific differences: (1) The study lakes have different morphometries that might affect the relative influence of evaporative processes (e.g., lake surface: volume ratio is noticeably lower $\left(\approx 0.43 \mathrm{~m}^{-1}\right)$ in La Caldera than Río Seco $\left(\approx 1.5 \mathrm{~m}^{-1}\right)$ (estimated from Morales-Baquero et al. [1999]); (2) Río Seco has a temporal outlet that drains water out of the lake during most part of the ice-free period, avoiding the accumulation of calcium derived from atmospheric inputs; and (3) Río Seco is partially surrounded by alpine meadows which can partially retain the $\mathrm{Ca}$ delivered by atmospheric deposition.

[27] The measurement of the annual cumulative deposition of calcium at $1000 \mathrm{~m}$ asl (Table 2) allowed us to estimate the contribution of atmosphere to the calcium content in the study lakes. The total amount of dissolved calcium from atmospheric inputs predicted to accumulate in the lake was calculated as the product between annual cumulative deposition of calcium (per square meter) and lake catchment area (Table 4). Despite the uncertainty that this estimation might involve, it strongly suggests that atmospheric inputs are enough to explain the calcium content of Sierra Nevada lakes.

[28] The biogeochemical role of dust deposition on aquatic and terrestrial ecosystems is now widely recognized [Okin et al., 2004; Jickells et al., 2005]. Changes in climate will presumably lead to alterations in the quantity and atmospheric delivery pattern of mineral aerosol and its associated elements of biogeochemical interest [Moulin et al., 1997; Prospero and Lamb, 2003]. Remote lakes can serve as sensors of these expected changes in dust deposi-

Table 4. Comparison Between Total Atmospheric Inputs of Calcium and Lake Calcium Content for Each of the Study Lakes

\begin{tabular}{|c|c|c|}
\hline & La Caldera Lake & Rio Seco Lake \\
\hline Annual cumulative $\mathrm{Ca}$ deposition, $\mathrm{mmol} \mathrm{m}^{-2}$ & 48 & 48 \\
\hline Lake catchment area, ${ }^{\mathrm{a}} \mathrm{m}^{2}$ & $23.510^{4}$ & $9.910^{4}$ \\
\hline Annual $\mathrm{Ca}$ deposition in the catchment, mol & 11300 & 4800 \\
\hline Ca retention by the catchment, ${ }^{\mathrm{b}} \%$ & 0 & 35 \\
\hline Annual atmospheric $\mathrm{Ca}$ input to the lake, mol & 11300 & 3100 \\
\hline Lake $\mathrm{Ca}$ concentration, $\mu \mathrm{mol} \mathrm{L} \mathrm{L}^{-1}$ & 110 & 37 \\
\hline Estimated lake volume, ${ }^{a} \mathrm{~L}$ & $4910^{6}$ & $310^{6}$ \\
\hline Lake $\mathrm{Ca}$ amount, mol & 5400 & 111 \\
\hline
\end{tabular}

${ }^{a}$ Morales-Baquero et al. [1999].

${ }^{\mathrm{b}} \mathrm{Ca}$ retention by vegetation estimated after Likens et al. [1977]. 
tion, a major biogeochemical force in freshwater ecosystems of the Mediterranean region, important enough not to be neglected in global change studies.

[29] Acknowledgments. The NASA-Goddard Space Flight Center Total Ozone Mapping Spectrometer group provided daily data on TOMS aerosol index. The authors gratefully acknowledge the NOAA Air Resources Laboratory (ARL) for the provision of the HYSPLIT transport and dispersion model and/or READY website http://www.arl.noaa.gov/ ready.html) used in this publication. The Sierra Nevada National Park Office allowed us to carry out this study in a protected area. We are grateful to J. R. Francia (CIFA, Granada, Spain) and to the director and technical staff of the Observatorio de Sierra Nevada (Instituto de Astrofísica de Andalucía, CSIC, Granada, Spain) for allowing us to install atmospheric deposition samplers. We are grateful to G. E. Likens and M. D. Löye-Pilot for insightful comments on a previous version of this manuscript. This research was supported by the projects CICYT AMB99-0541 and CICYT REN03-03038 and a FPI grant from Spanish Government to Elvira PulidoVillena.

\section{References}

Ansmann, A., et al. (2003), Long-range transport of Saharan dust to northern Europe: The 11-16 October 2001 outbreak observed with EARLINET, J. Geophys. Res., 108(D24), 4783, doi:10.1029/2003JD003757.

Avila, A., I. Queralt-Mitjans, and M. Alarcón (1997), Mineralogical composition of African dust delivered by red rains over northeastern Spain, J. Geophys. Res., 102(D18), 21,977-21,996.

Avila, A., M. Alarcón, and I. Queralt-Mitjans (1998), The chemical composition of dust transported in red rains-Its contribution to the biogeochemical cycle of a holm oak forest in Catalonia (Spain), Atmos. Environ., 32, 179-191.

Baines, S., K. E. Webster, T. K. Kratz, S. R. Carpenter, and J. J. Magnuson (2000), Synchronous behavior of temperature, calcium, and chlorophyl in lakes of northern Wisconsin, Ecology, 81, 815-825.

Catalan, J., et al. (2002), Seasonal ecosystem variability in remote mountain lakes: Implications for detecting climatic signals in sediment records, J. Paleolimnol., 28, 25-46.

Chiapello, I., J. M. Prospero, J. R. Herman, and N. C. Hsu (1999), Detection of mineral dust over the North Atlantic Ocean and Africa with the Nimbus 7 TOMS, J. Geophys. Res., 104(D8), 9277-9291.

D'Almeida, G. A. (1986), A model for Saharan dust transport, J. Clim. Appl. Meteorol., 24, 903-916.

Draxler, R. R., and G. D. Rolph (2003), HYSPLIT (HYbrid Single-Particle Lagrangian Integrated Trajectory) Model, http://www.arl.noaa.gov/ready/ hysplit4.html, NOAA Air Resour. Lab., Silver Spring, Md.

Drever, J. I. (1982), The Geochemistry of Natural Waters, Prentice-Hall, Upper Saddle River, N. J.

Drouet, T., J. Herbauts, W. Gruber, and D. Demaiffe (2005), Strontium isotope composition as a tracer of calcium sources in two forest ecosystems in Belgium, Geoderma, 126, 203-223.

Escudero, M., S. Castillo, X. Querol, A. Avila, M. Alarcon, M. M. Viana, A. Alastuey, E. Cuevas, and S. Rodríguez (2005), Wet and dry African dust episodes over eastern Spain, J. Geophys. Res., 110, D18S08, doi:10.1029/2004JD004731

Hultberg, H., and M. Ferm (2004), Temporal changes and fluxes of sulphur and calcium in wet and dry deposition, internal circulation as well as in run-off and soil in a forest at Gårdsjön, Sweden, Biogeochemistry, 68, $355-363$

Huntington, T. G. (2000), The potential for calcium depletion in forest ecosystems of southeastern United States: Review and analysis, Global Biogeochem. Cycles, 14, 623-638.

Jaenicke, R., and L. Schütz (1978), Comprehensive study of physical and chemical properties of the surface aerosols in the Cape Verde Islands region, J. Geophys. Res., 83(C7), 3585-3589.

Jickells, T. D., et al. (2005), Global iron connections between desert dust, ocean biogeochemistry, and climate, Science, 308, 67-71.

Kopáček, J., L. Procházková, E. Stuchlík, and P. Blažka (1995), The nitrogen-phosphorus relationship in mountain lakes: Influence of atmospheric input, watershed, and $\mathrm{pH}$, Limnol. Oceanogr., 40, 930-937.

Kopáček, J., J. Jejzlar, E. Stuchlík, J. Fott, and J. Veselý (1998), Reversibility of acidification of mountain lakes after reduction in nitrogen and sulphur emissions in Central Europe, Limnol. Oceanogr., 43, 357-361.

Kopáček, J., J. Kaňa, H. Santrůčková, T. Picek, and E. Stuchlík (2003), Chemical and biochemical characteristics of alpine soils in the Tatra Mountains and their correlation with lakewater quality, Water Air Soil Pollut., 153, 307-327.
Krám, P., J. Hruška, B. S. Wenner, C. T. Driscoll, and C. E. Johnson (1997), The biogeochemistry of basic cations in two forest catchments with contrasting lithology in the Czech Republic, Biogeochemistry, 37, 173-202.

Lange, G. (1960), Die Calina - der Staubdunst des spanischen Sommers, Arch. Meteorol. Geophys. Bioklimatol., Ser. B, 10, 396-403.

Likens, G. E., F. H. Bormann, R. S. Pierce, J. S. Eaton, and N. M. Johnson (1977), Biogeochemistry of a Forested Ecosystem, 146 pp., Springer, New York.

Likens, G. E., et al. (1998), The biogeochemistry of calcium in Hubbard Brook, Biogeochemistry, 41, 89-173.

Löye-Pilot, M. D., J. M. Martin, and J. Morelli (1986), Influence of Saharan dust on the rain acidity and atmospheric input to the Mediterranean, Nature, 321, 427-428

Magnuson, J. J., B. J. Benson, and T. K. Kratz (1990), Temporal coherence in the limnology of a suite of lakes in Wisconsin, U.S.A., Freshwater Biol., 23, 145-149.

Milliman, J. D. (1993), Production and accumulation of calcium-carbonate in the ocean- budget of a non-steady state, Global Biogeochem. Cycles, 7 , 927-957.

Morales-Baquero, R., P. Carrillo, I. Reche, and P. Sánchez-Castillo (1999), Nitrogen-phosphorus relationship in high mountain lakes: Effects of the size of catchment basins, Can. J. Fish. Aquat. Sci., 56, 1809-1817.

Morales-Baquero, R., E. Pulido-Villena, and I. Reche (2006), Atmospheric inputs of phosphorus and nitrogen to the southwest Mediterranean region: Biogeochemical responses of high mountain lakes, Limnol. Oceanogr., $51,830-834$.

Moreno, T., X. Querol, A. Alastuey, M. Viana, and W. Gibbons (2005), Exotic dust incursions into central Spain: Implications for legislative controls on atmospheric particulates, Atmos. Environ., 39, 6109-6120.

Moulin, C., E. C. Lambert, F. Dulac, and U. Dayan (1997), Control of atmospheric export of dust from North Africa by the North Atlantic Oscillation, Nature, 387, 691-694.

Okin, G. S., N. Mahowald, O. A. Chadwick, and P. Artaxo (2004), Impact of desert dust on the biogeochemistry of phosphorus in terrestrial ecosystems, Global Biogeochem. Cycles, 18, GB2005, doi:10.1029 2003GB002145.

Prospero, J. M., and P. J. Lamb (2003), African droughts and dust transport to the Caribbean: Climate change implications, Science, 302, 10241027.

Psenner, R. (1999), Living in a dusty world: Airborne dust as a key factor for alpine lakes, Water Air Soil Pollut., 112, 217-227.

Psenner, R., and U. Nickus (1986), Snow chemistry of a glacier in the Central Eastern Alps (Hintereisferner, Tyrol, Austria), Z. Gletscherkd. Glazialgeol., 22, 1-18.

Puga, E. (1976), Investigaciones petrológicas de Sierra Nevada, Univ. de Granada, Granada, Spain.

Pulido-Villena, E. (2004), The role of atmospheric deposition on the biogeochemistry of high mountain lakes (Sierra Nevada, Spain) (in Spanish), Ph.D. thesis, 296 pp., Univ. of Granada, Granada, Spain.

Rodriguez, S., X. Querol, A. Alastuey, G. Kallos, and O. Kakaliagou (2001), Saharan dust contributions to PM10 and TSP levels in Southern and Eastern Spain, Atmos. Environ., 35, 2433-2447.

Rogora, M., R. Mosello, and A. Marchetto (2004), Long-term trends in the chemistry of atmospheric deposition in northwestern Italy: The role of increasing Saharan dust deposition, Tellus, Ser. B, 56, 426-434

Rolph, G. D. (2003), Real-time Environmental Applications and Display sYstem (READY), http://www.arl.noaa.gov/ready/hysplit4.html, NOAA Air Resour. Lab., Silver Spring, Md.

Schlesinger, W. H. (1997), Biogeochemistry, Elsevier, New York.

Schlesinger, W. H., J. T. Gray, and F. S. Gilliam (1982), Atmospheric deposition processes and their importance as sources of nutrients in a chaparral ecosystem of southern California, Water Resour. Res., 18, 623 629.

Schütz, L., R. Jaenicke, and H. Pietrek (1981), Saharan dust transport over the North Atlantic Ocean, in Desert Dust, edited by T. L. Péwé, Spec. Pap. Geol. Soc. Am., 186, 87-100.

Skjelkvåle, B. L., and R. F. Wright (1998), Mountain lakes: Sensitivity to acid deposition and global climate change, Ambio, 27, 280-286.

Sokal, R. R., and F. J. Rohlf (1995), Biometry, W. H. Freeman, New York. Stoddard, J. L., et al. (1999), Regional trends in aquatic recovery from acidification in North America and Europe, Nature, 401, 575-578.

Sullivan, T. J., D. F. Charles, J. P. Smol, B. F. Cumming, A. R. Selle, D. R. Thomas, J. A. Bernert, and S. S. Dixit (1990), Quantification of changes in lakewater chemistry and response to acidic deposition, Nature, 345 , $54-58$.

Swap, R., S. Ulanski, M. Cobbett, and M. Garstang (1996), Temporal and spatial characteristics of Saharan dust outbreaks, J. Geophys. Res. 101(D2), 4205-4220. 
Tait, D., and B. Thaler (2000), Atmospheric deposition and lake chemistry trends at a high mountain site in the eastern Alps, J. Limnol., 59, 61-71.

Talbot, R. W., R. C. Harriss, E. V. Browell, G. L. Gregory, D. I. Sebacher, and S. M. Beck (1986), Distribution and geochemistry of aerosols in the tropical north Atlantic troposphere: Relationship to Saharan dust, J. Geophys. Res., 91(D4), 5173-5182.

Torres, O., P. K. Bhartia, J. R. Herman, and Z. Ahmad (1998), Derivation of aerosol properties from satellite measurements of backscattered ultraviolet radiation: Theoretical basis, J. Geophys. Res., 103(D18), 23,32123,322 .

Torres, O., P. K. Bhartia, J. R. Herman, A. Sinyuk, and B. Holben (2002), A long term record of aerosol optical thickness from TOMS observations and comparison to AERONET measurements, J. Atmos. Sci., 59, $398-$ 413.

Ventura, M., L. Camarero, T. Buchaca, F. Bartumeus, D. M. Livingstone, and J. Catalan (2000), The main features of seasonal variability in the external forcing and dynamics of a deep mountain lake (Redó, Pyrenees), J. Limnol., 59, 97-108.

Wathne, B. M., and B. O. Rosseland (Eds.) (2000), Measuring and modelling the dynamic response of remote mountain lake ecosystems to environmental change: A programme of Mountain Lake Research-MOLAR, MOLAR Final Rep. 4/1999, Norw. Inst. for Water Res. (NIVA), Oslo.

Webster, K. E., T. K. Kratz, C. J. Bowser, and J. J. Magnuson (1996), The influence of landscape position on lake chemical responses to drought in northern Wisconsin, Limnol. Oceanogr., 41, 977-984.

R. Morales-Baquero and I. Reche, Departamento de Ecología, Facultad de Ciencias, Universidad de Granada, 18071 Granada, Spain.

E. Pulido-Villena, Laboratoire d'Océanographie de Villefranche-sur-Mer, CNRS-UMR 7093, Caserne Nicolas, Quai de la Darse, BP 8, F-06238 Villefranche-sur-Mer, France. (elvira.pulido-villena@obs-vlfr.fr) 